\title{
Transformation of Phage-sensitivity in Bacillus subtilis
}

\author{
By S. HOR V ÁjT H \\ Institute of Genetics, Hungarian Academy of Sciences, Budapest, Hungary
}

(Accepted for publication 29 May 1969)

\begin{abstract}
SUMMARY
Two methods were developed to demonstrate a small fraction $\left(10^{-4}\right)$ of phage-sensitive cells in a phage-resistant population with a high degree of accuracy, using the plexiglass phage titration method (Horváth \& Alföldi, I954).

Phage-sensitivity was transferable by DNA isolated from Bacillus subtilis $\mathrm{I} 68 \mathrm{M} \mathrm{trp}{ }^{+} p h s$ (SPO-I phage-sensitive) to the recipient strain of $168 \mathrm{~m}$ trp phr (SPO-I phage-resistant) in transformation experiments. The number of $\mathrm{I} 68 \mathrm{M} \mathrm{trp} p^{+}$phs transformants was a function of the concentration of the transforming DNA. The trp ${ }^{+}$and $p h s$ characters are not linked. The competence curves for the number of I68 $\mathrm{M} \mathrm{trp} p^{+} p h r$ and I $68 \mathrm{M} \mathrm{trp}{ }^{+} p h s$ transformants were similar. The phenotypic lag was found to be $5 \mathrm{hr} 30 \mathrm{~min}$. The maximum frequency of $168 \mathrm{M} t r p^{+}$phs cells among the transformants was 2 to $5 \%$.
\end{abstract}

\section{INTRODUCTION}

A wide range of bacterial characters are transferable (Ravin, I96r) and Horváth, (1969) succeeded in transforming phage-resistance in Bacillus subtilis.

The present investigation demonstrates the transformation of phage-sensitivity.

\section{METHODS}

Bacterial and phage strains. For transformation the recipient strain was a spontaneous SPO-I phage resistant mutant of Bacillus subtilis $168 \mathrm{~m}$ trp phs designated I $68 \mathrm{M}$ trp phr. Phage-sensitive spontaneous mutants were found among the I68 $\mathrm{m}$ trp phr bacteria and the rate of mutation was $5.82 \times 1 \mathrm{IO}^{-5}$ mutations per bacterium per generation calculated according to Luria \& Delbrück (1943). DNA was prepared from B. subtilis $\mathrm{I} 68 \mathrm{~m}$ trp phs and I68 м trp phr strains after transformation to prototrophy.

Media. Bacterial strains were maintained on potato agar (Spizizen, I958). The recipient strain was precultivated on minimal glucose yeast agar slope (MGY agar); competent cells were prepared in MGY liquid medium; T medium was used for transformation and MG agar for the selection of I $68 \mathrm{M} \mathrm{trp}{ }^{+}$phr transformants (Horváth, I967).

Transforming DNA from the donor strains was prepared by the phenol extraction method of Saito \& Miura (1963).

The titration of phage was carried out by the plastic tray method (Horváth \& Alföldi, I954).

Transformation procedure. An overnight culture of 168 м trp phr on MGY agar slope was suspended in $10 \mathrm{ml}$. liquid medium in a $100 \mathrm{ml}$. Erlenmeyer flask, fitted with a side arm for densitometry measurement. The optical density (OD) of the 
bacterial suspension was 0.025 , which contained $9.6 \times 10^{5}$ colony forming $\mathrm{u} . / \mathrm{ml}$. The culture was incubated in a water bath at $37^{\circ}$ on a reciprocal shaker at $100 \mathrm{rev} . / \mathrm{min}$. (Horváth, I967). When the bacterial cells reached the peak of competence (OD I.5) the cell suspension was diluted in T medium to $0.4 \mathrm{OD}$. To $0.25 \mathrm{ml}$. of this suspension $0.75 \mathrm{ml}$. DNA solution in T medium was added to give a final DNA concentration of $5 \mu \mathrm{g} . / \mathrm{ml}$. and shaken for $30 \mathrm{~min}$. in a water bath at $37^{\circ}$. Finally, $0.25 \mathrm{ml}$. of this mixture was measured into a $50 \mathrm{ml}$. Erlenmeyer flask containing $4.75 \mathrm{ml}$. MG liquid medium with $0.1 \%$ casein hydrolysate and after 14 to $15 \mathrm{hr}$ incubation at $37^{\circ}, 0.05 \mathrm{ml}$. of the bacterial suspension was transferred to $2 \mathrm{ml}$. MG liquid medium containing $0.1 \%$ casein hydrolysate. The suspension was shaken in a water bath at $37^{\circ}$, and after 3 to $4 \mathrm{hr}$ the number of phage-sensitive cells as I68 $\mathrm{M} \mathrm{trp} p^{+}$phs transformants was measured according to the following two methods. This transformation procedure yields qualitative rather than quantitative results.

\section{Measurement of the number of SPO-I phage-sensitive cells in phage-resistant populations}

I. One-step growth curve method. I68 $M$ trp phr and I68 $M$ trp phs cell suspensions in early exponential growth were used (OD $0 \cdot 3$ ). Different numbers of $\mathrm{I} 68 \mathrm{M}$ trp phs cells in $0.5 \mathrm{ml}$. volumes were added to $\mathrm{I} \mathrm{ml}$. phage resistant $\mathrm{I} 68 \mathrm{M} \operatorname{trp}$ cells. $2 \times 10^{6}$ SPO-I phage particles in $0.5 \mathrm{ml}$. volumes were then added to each tube. These cultures were shaken in a water bath at $37^{\circ}$ for $5 \mathrm{~min} .0 . \mathrm{I} \mathrm{ml}$. of these suspension were diluted in Io $\mathrm{ml}$. MGY liquid media and incubation was continued for I hr. Samples were taken and one-step growth curves were determined from the plaque forming units (p.f.u.). The higher the number of phage-sensitive cells in the phage-resistant population, the higher the titre of the plateau. The plaque titre at the plateau in log units was designated $T_{c}$ for the control phage-resistant bacterial suspension and $T_{e}$ for the bacterial suspensions which contained phage-sensitive cells. The difference $T_{e}-T_{c}$, designated $D$, was used in the transformation experiments to assay the number of phage-sensitive cells present among the $168 \mathrm{~m} t r p^{+} p h r$ transformants.

2. The phage, anti-phage serum method. To $0.5 \mathrm{ml}$. phage-resistant cell suspension after transformation $0.25 \mathrm{ml}$. SPO-I phage $\left(4 \times 10^{7}\right.$ p.f.u. $/ \mathrm{ml}$.) was added and shaken at $37^{\circ}$ for $10 \mathrm{~min}$. Then $0.25 \mathrm{ml}$. anti-SPO-I phage serum (K value 25 ) was added and incubation continued for a further Io min. at $37^{\circ}$. The number of infective centres was then assayed using I68 $\mathrm{M}$ trp phs as indicator bacteria.

\section{RESULTS AND DISCUSSION}

\section{Transformation of phage-sensitivity}

To investigate the transformation of phage-sensitivity, undiluted $168 \mathrm{м} \operatorname{trp} p h r$ competent cells were used in the experiment. The $D$ value was $\mathrm{I} \cdot 357$ when transformation was carried out with DNA isolated from I $68 \mathrm{~m} \mathrm{trp}^{+}$phs and $5 \%$ of phage-sensitive cells were found among the trp ${ }^{+}$transformants. When DNA isolated from I68 $\mathrm{m} t r p^{+}$ $p h r$ was used in transformation the number of phage-sensitive cells was very low ( $D=-0.153)$ and not higher than with the control strain, I68 м trp phr.

When transforming DNA was treated with $50 \mu \mathrm{g} . / \mathrm{ml}$. DNase before transformation, no transformants could be detected. 


\section{Effect of DNA concentration}

Different quantities of transforming DNA isolated from $168 \mathrm{M} t r p^{+} p h s$ cells were added to the undiluted competent $\mathrm{I} 68 \mathrm{M}$ trp phr cells, and the $D$ values were measured. The number of $\mathrm{I} 68 \mathrm{M} t r p^{+} p h s$ transformants was a function of the DNA concentration. The dose-effect curve calculated from the number of $168 \mathrm{M} \mathrm{trp} p^{+} p h s$ transformants was steeper than $45^{\circ}$, which shows that the $t r p^{+}$and phs markers are not linked. When markers are far apart, double transformants are found only at saturating levels of DNA (Goodgal, I96I; Michel, Sicard \& Ephrussi-Taylor, I964; Kelly, I967).

\section{The competence curve}

The competence curve based upon the number of $\mathrm{I} 68 \mathrm{M} t r p^{+} p h r$ transformants was the same as that found earlier. The characteristics of the competence curve for $168 \mathrm{M}$ trp ${ }^{+}$phs transformants were also similar to those obtained previously (Horváth, I967, I968).

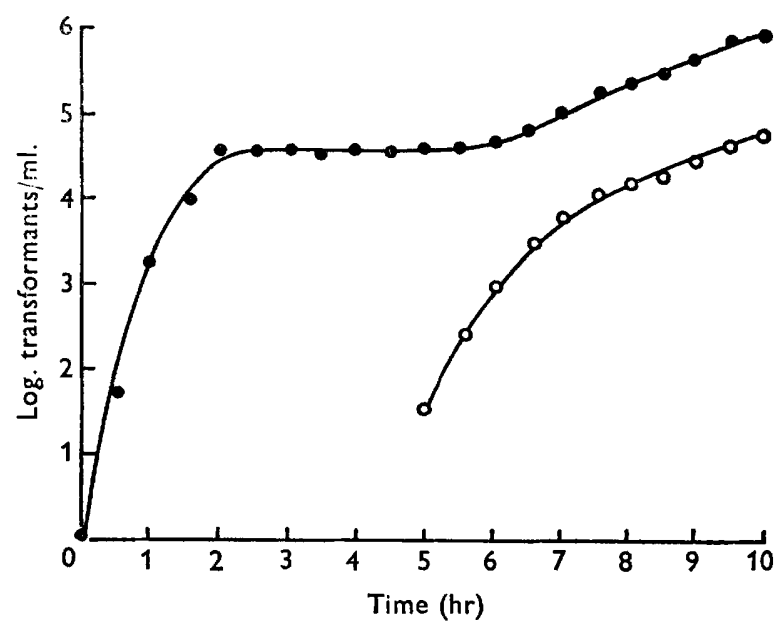

Fig. I. The number of $t r p^{+} p h r$ and $t r p^{+} p h s$ cells during transformation. $t r p^{+} p h r$ transformants; O- - , I68 м trp ${ }^{+} p h s$ transformants; I $68 \mathrm{~m}$ trp phr bacteria were transformed with DNA from $168 \mathrm{M} t r p^{+} p h s$. The number of $t r p^{+} p h s$ transformants was measured using the phage, antiphage serum method. o is the time when DNA was added.

\section{Assay of trp ${ }^{+}$phr and trp ${ }^{+}$phs bacteria during transformation}

$168 \mathrm{M}$ trp phr competent cells were used to measure the number of $t r p^{+} p h r$ and $t r p^{+}$ $p h s$ bacteria during transformation. DNA isolated from I68 $\mathrm{m} t r p^{+} p h s$ was added to the cell suspension and incubated at $37^{\circ}$ for $30 \mathrm{~min} .0 .5 \mathrm{ml}$. was then measured into three flasks each containing $9.5 \mathrm{ml}$. MG liquid medium with $0.1 \%$ casein hydrolysate. A control without DNA was included. $0.9 \mathrm{ml}$. samples were taken during incubation and $0 . \mathrm{I} \mathrm{ml}$. DNase $(30 \mu \mathrm{g}$.) was then added and incubation continued for $5 \mathrm{~min}$. The $t r p^{+} p h r$ transformants were selected on MG agar. The number of $t r p^{+}$ phs transformants was measured by the phage, antiphage serum method (Fig. I).

After subtraction of the control values, the curve for $t r p^{+} p h s$ transformants was obtained. The phenotypic lag was about $5 \mathrm{hr} 30 \mathrm{~min}$. A concomitant rise in the number 
of $t r p^{+} p h r$ as well as the $t r p^{+} p h s$ transformants was observed during incubation. The frequency of the $t r p^{+} p h s$ among the $t r p^{+} p h r$ transformants was about $3 \%$, calculated from the corrected values.

Sensitivity of trp ${ }^{+}$phr and trp ${ }^{+}$phs transformants to phage SPO-I

Suitable bacterial dilutions were spread on MGY agar to obtain 60 to 80 colonies per plate. 4 to $5 \%$ of these colonies were SPO-I phage sensitive in tests employing the replica plating technique (Lederberg \& Lederberg, 1952). Six phage-sensitive and ten phage-resistant colonies were tested. The phage-sensitive colonies gave high $D$ values and phage-resistant colonies gave very low $D$ values. Intermediate $D$ values were not observed.

I am grateful to the Director Dr B. Györffy for his valuable criticism and Irene Kállay for her skilled technical assistance.

\section{REFERENCES}

Goodgal, S. H. (196I). Studies on transformation of Hemophilus influenzae. IV. Linked and unlinked transformations. J. gen. Physiol. 45, 205.

HoRvÁth, S. (1967). Development of competence in cultures of Bacillus subtilis inoculated with different numbers of bacteria. J. gen. Microbiol. 48, 215 .

Horváth, S. (1968). Competence in Bacillus subtilis transformation system. J. gen. Microbiol. 51, 85.

HoRvÁTH, S. (1969). Transformation of phage-resistance in Bacillus subtilis. Experientia 25, 3 I 2.

HoRVÁth, S. \& AlFöLDI, L. (1954). A new and sensitive method of phage titration on plastic trays. Acta microbiol. hung. I, 495.

KeLLY, M. S. (1967). The causes of instability of linkage in transformation of Bacillus subtilis. Molec. gen. Genetics 99, 350.

LeDerberG, J. \& LeDERBERG, E. M. (I952). Replica plating and indirect selection of bacterial mutants. J. Bact. 63, 399.

LuRIA, S. R. \& DelbrüCK, M. (1943). Mutations of bacteria from virus sensitivity to virus resistance. Genetics, Princeton 28, 49 I.

Michel, J. F., Sicard, A. M. \& Ephrussi-Taylor, E. (I964). Comparaison de deux methodes d'études de liasons faibles dans la transformation du pneumocoque. Expl Cell Res. 36, 368.

Ravin, A. W. (I96I). The genetics of transformation. Adv. Genet. ro, 6I.

SaIto, H. \& MiURA, K. I. (I963). Preparation of transforming deoxyribonucleic acid by phenol treatment. Biochim. biophys. Acta 72, 6I9.

SPIZIZEN, J. (1958). Transformation of a biochemically deficient strain of Bacillus subtilis by deoxvribonucleate. Proc. natn. Acad. Sci. U.S.A. 44, 1072. 